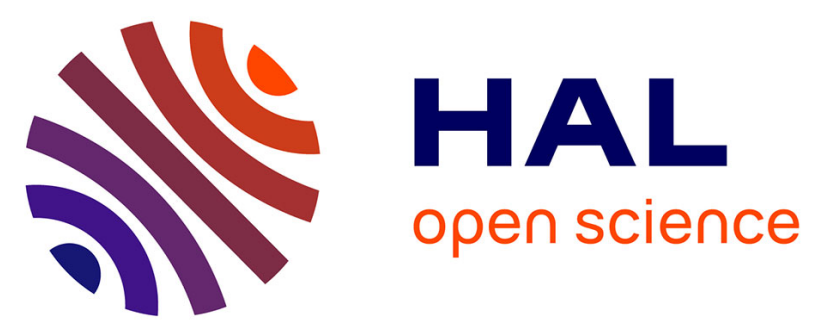

\title{
Intensive care medical procedures are more complicated, more stressful, and less comfortable with Ebola personal protective equipment: A simulation study
}

Guillaume Grillet, Nicolas Marjanovic, Jean-Marc Diverrez, Pierre Tattevin, Jean-Marc Tadié, Erwan L'her

\section{To cite this version:}

Guillaume Grillet, Nicolas Marjanovic, Jean-Marc Diverrez, Pierre Tattevin, Jean-Marc Tadié, et al.. Intensive care medical procedures are more complicated, more stressful, and less comfortable with Ebola personal protective equipment: A simulation study. Journal of Infection, 2015, 71 (6), pp.703-706. 10.1016/j.jinf.2015.09.003 . hal-01205356

\section{HAL Id: hal-01205356 \\ https://hal-univ-rennes1.archives-ouvertes.fr/hal-01205356}

Submitted on 21 Oct 2015

HAL is a multi-disciplinary open access archive for the deposit and dissemination of scientific research documents, whether they are published or not. The documents may come from teaching and research institutions in France or abroad, or from public or private research centers.
L'archive ouverte pluridisciplinaire HAL, est destinée au dépôt et à la diffusion de documents scientifiques de niveau recherche, publiés ou non, émanant des établissements d'enseignement et de recherche français ou étrangers, des laboratoires publics ou privés. 


\section{Intensive care medical procedures are more complicated, more}

\section{2 stressful, and less comfortable with Ebola personal protective}

\section{equipment: A simulation study}

4

5

Guillaume Grillet $^{\mathrm{a}}$, Nicolas Marjanovic ${ }^{\mathrm{b}}$, Jean-Marc Diverrez ${ }^{\mathrm{c}}$, Pierre Tattevin ${ }^{\text {a, }}$, JeanMarc Tadiéa ${ }^{a}$ Erwan L'Her ${ }^{c, d}$

${ }^{a}$ Service des Maladies Infectieuses et de Réanimation Médicale, Hôpital Pontchaillou, rue Henri Le Guilloux, 35000 Rennes, France

${ }^{b}$ Service d'Accueil des Urgences, Hôpital de la Cavale Blanche, 29200 Brest, France ${ }^{c}$ Institut de Recherche Technologique B-Com, 25 rue Claude Chappe, 29280 Plouzané,

France

${ }^{d}$ Service de Réanimation Médicale, Hôpital de la Cavale Blanche, 29200 Brest, France ;

Centre de Simulation en Santé, Université de Bretagne Occidentale ; LATIM INSERM UMR 1101, Brest, France

Corresponding author: Pierre Tattevin, Service des Maladies Infectieuses et de Réanimation Médicale, Hôpital Pontchaillou, rue Henri Le Guilloux, 35000 Rennes, France; tel +33 $299289564 ; \mathrm{Fax}+33299282452$

E-mail addresses: guillaume.grillet@chu-rennes.fr; nicolas.marjanovic@chu-brest.fr; jeanmarc.diverrez@chu-brest.fr; pierre.tattevin@chu-rennes.fr; jean-marc.tadie@chu-rennes.fr; erwan.lher@chu-brest.fr

Running Title Impact of Ebola personal protective equipment Keywords

Ebola virus disease; Intensive care; Protective equipment; Stress; Workload; Task performance 


\section{To the editor}

Ebola virus disease (EVD) is a life-threatening condition. Appropriate management of organ failure, hemodynamic instability, and metabolic disorders significantly improves survival. This implies that life-saving procedures are undertaken in case of need, including endotracheal intubation, nasogastric tube placement and central venous catheter (CVC) insertion. The challenge is to provide high quality of care to patients with life-threatening EVD, under optimal safety conditions for health care workers, i.e. with reinforced personal protective equipment (PPE), ensuring that no exposure to patient blood or any other body fluid occur [1-3]. We assessed the impact of Ebola PPE use on the performance of senior ICU physicians during common intensive care unit (ICU) procedures, and on the workload, in a simulation environment.

The study was performed in our simulation department. Thirteen volunteer senior ICU physicians performed orotracheal intubation and nasogastric tube placement on a simulation mannequin (Megacode Kelly Sim, Laerdal ${ }^{\mathrm{TM}}$, Stavanger, Norway), and CVC insertion on a dedicated echogeneous task trainer (CAE Healthcare ${ }^{\mathrm{TM}}$, St Laurent, QC, Canada). The use of ultrasound for CVC insertion was left to the discretion of the physician. Each participant had to complete all procedures twice, one with standard protection, and one with Ebola PPE, in an order determined by the randomization. The Ebola PPE consisted in a N95 Particulate Filtering Face Respirator, with large protective glasses, surgical hood, fluid resistant coveralls, boot covers, and two pairs of gloves, as recommended [4]. All sequences were recorded using an HD video camera. Participants were equipped with a thoracic belt for the monitoring of heart rates and chest wall movements to record upper body tilt (Zephyr BioHarness $3^{\mathrm{TM}}$, Annapolis, USA). Procedural time was independently assessed by two reviewers, using a video tagging software (StudioCode ${ }^{\mathrm{TM}}$, Marseille, France). Equipment ergonomics were assessed for each participant after the complete course, using a Likert scale 
asking three questions for each procedure: i) stress during the task (from 1, major stress to 5, no stress); ii) equipment's ease of use (from 1, very difficult to 5, very easy), and iii) comfort (from 1, very uncomfortable to 5, very comfortable). The task workload was assessed using the National Aeronautics and Space Administration Task Load Index (NASA-TLX), a multifaceted tool for perceptual (subjective) workload evaluation [5], based on a weighted average of ratings on six subscales: mental demand, physical demand, temporal demand, performance, effort, and frustration. These steps provide a global score from 0 to 100, higher values indicating heavier workload. All tests were performed using Statview 5.0.1 (SAS Institute, Cary, NC, USA). Mann-Whitney and Kruskall Wallis non-parametric tests were used for procedural time analysis and Likert scale comparisons. Physiological parameters comparison used a Laird and Ware regression test with R [6], and the lme4 library [7]. NASA-TLX data were compared using a non-parametric Wilcoxon test. Data are provided as median [interquartile ratio], unless specified otherwise.

Global success rate for the complete procedure course was $100 \%$ with standard protection, and $85 \%$ with Ebola PPE $(p=0.48)$. Higher degrees of body tilt were measured with Ebola PPE, as compared to standard protection $(p<0.05)$. In most cases, procedures were rated as easier, and more comfortable with standard protection, than with Ebola PPE (Table 1). Median global task load index was higher with Ebola PPE, as compared to standard protection, for orotracheal intubation (44.3 vs. 20.3, $\mathrm{p}=0.007$ ), and nasogastric placement (38.9 vs. $25.6, \mathrm{p}=0.008$, Figure 1 ). For CVC insertion, global task load index was not significantly different for the whole group ( 58.6 vs. 37.6, $\mathrm{p}=0.182$ ). However, differences were significant for the 7 physicians who performed ultrasound-guided procedures $(54.9$ [34.7-67.1] vs. 29.5 [14.1-50.1], $p=0.028)$, but not for the 6 physicians who didn't use ultrasound (76 [52.9-84.9] vs. 46.3 [36-58.9], $p=0.686$ ). Physical demand was higher with Ebola PPE as compared to standard protection for nasogastric tube placement (2.5 [0.9-5.2] 
vs. $0.6[0.4-0.9], p=0.022)$, and CVC insertion (3.6 [1.8-13.4] vs. $1.2[0.4-2.5], p=0.009)$, but nor for orotracheal intubation.

Although these findings are not unexpected given the constraints and discomfort of Ebola PPE reported by health care workers, the application of simulation procedures in this study provided evidence-based, and quantitative data, on the impact of currently recommended Ebola PPE on these life-saving procedures. This innovative model may be used to compare different combinations of Ebola PPE, and select those with lower impact on quality of care and workload, while still ensuring effective protection. Person-to-person transmission of Ebola virus primarily occurs through contact with infected patients' fluids [13]. During ICU procedures, often performed in emergency, physicians are at risk for contamination [7-9], and the use of a dedicated Ebola PPE is mandatory. All health care providers potentially involved must receive adequate training for correct use of Ebola PPE, including safety (i.e. no breaches in protection), and efficacy (i.e. being able to provide appropriate care with maximum ease, dexterity, comfort, and minimal stress) $[3,4]$. Because the management of patients with EVD is a complex process, simulation plays a major role in the preparation of health care worker to anticipate the difficulties that may arise while taking care of patients suspected of, or confirmed with, EVD [10].

Our study has limitations. First, sample size was limited. However, this study was performed in a homogeneous group of senior, experienced ICU physicians. Second, the use of manikins, in a simulated environment, is merely a proxy for the actual clinical scenario. However, only simulated conditions enables to perform a standardized, randomized study, with prospective collection of an extensive set of data, and extensive post-hoc debriefing. We found that common ICU procedures are more complicated, more stressful, and less comfortable, with Ebola PPE. These necessary protections increase workload, and may be associated with increased risk of severe adverse events, either for the patient (procedure 
100 failure, complications), or the physician (Ebola virus transmission). Ebola PPE should be

101 evaluated by simulation and ergonomics studies as the one reported herein, to optimize the

102 selection of Ebola PPE that would ensure both the safety of health care workers, and the

103 quality of care for patients suspected of EVD.

104

105 Transparency declaration

106 All authors: no potential conflict of interest.

107

108 Acknowledgment

109 The authors thank all the physicians from the French Medical Intensive Care Training Team

110 of Western France, and the dedicated technicians from the simulation department of Brest

111 University of Medicine, who made this study possible.

112

113 Highlights

114 - This simulation study analyzed the impact of Ebola personal protective equipment (PPE)

115 on ICU procedures

116 - Nasogastric tube, central venous catheter, and orotracheal intubation are adversely

117 affected by Ebola PPE

118 - This model may be used for the selection of Ebola PPE with limited impact on ICU

119 procedures

120

121 


\section{References}

123 1. Shears P, O’Dempsey TJD. Ebola virus disease in Africa: epidemiology and nosocomial 124 transmission. J Hosp Infect. 2015;90(1):1-9.

125 126

2. Cohen J. Infectious diseases. When Ebola protection fails. Science. 2014;346(6205):178.

3. Rouveix E, Madougou B, Pellissier G, Diaougah H, Saley SM, de Truchis P, et al. Promoting the Safety of Healthcare Workers in Africa: From HIV Pandemic to Ebola Epidemic. Infect Control Hosp Epidemiol. 2015;36(3):361-2.

4. $\mathrm{WHO} \mid \mathrm{WHO}$ updates personal protective equipment guidelines for Ebola response [Internet]. WHO. [cited 2015 Aug 13]. Available from: http://www.who.int/mediacentre/news/releases/2014/ebola-ppe-guidelines/en/

5. Hart SG, Staveland LE. Development of NASA-TLX (Task Load Index): Results of Empirical and Theoretical Research. In: Meshkati PAH and N, editor. Advances in Psychology [Internet]. North-Holland; 1988 [cited 2015 Aug 13]. p. 139-83. Available from: http://www.sciencedirect.com/science/article/pii/S0166411508623869

6. Dean CB, Nielsen JD. Generalized linear mixed models: a review and some extensions. Lifetime Data Anal. 2007;13(4):497-512.

7. Zhang H, Lu N, Feng C, Thurston SW, Xia Y, Zhu L, et al. On fitting generalized linear mixed-effects models for binary responses using different statistical packages. Stat Med. 2011;30(20):2562-72.

8. Wolf T, Kann G, Becker S, Stephan C, Brodt H-R, de Leuw P, et al. Severe Ebola virus disease with vascular leakage and multiorgan failure: treatment of a patient in intensive care. Lancet. 2015;385(9976):1428-35.

9. Markovic-Denic L, Maksimovic N, Marusic V, Vucicevic J, Ostric I, Djuric D. Occupational exposure to blood and body fluids among health-care workers in Serbia. Med Princ Pract Int J Kuwait Univ Health Sci Cent. 2015;24(1):36-41.

10. Gaba DM. Simulation as a critical resource in the response to Ebola virus disease. Simul Healthc J Soc Simul Healthc. 2014;9(6):337-8. 
151 Figure 1. National Aeronautics and Space Administration Task Load Index (NASA-TLX) for

152 orotracheal intubation (1A), nasogastric tube placement (1B), and central venous catheter

153 insertion (1C), with Ebola or standard personal protective equipment

154

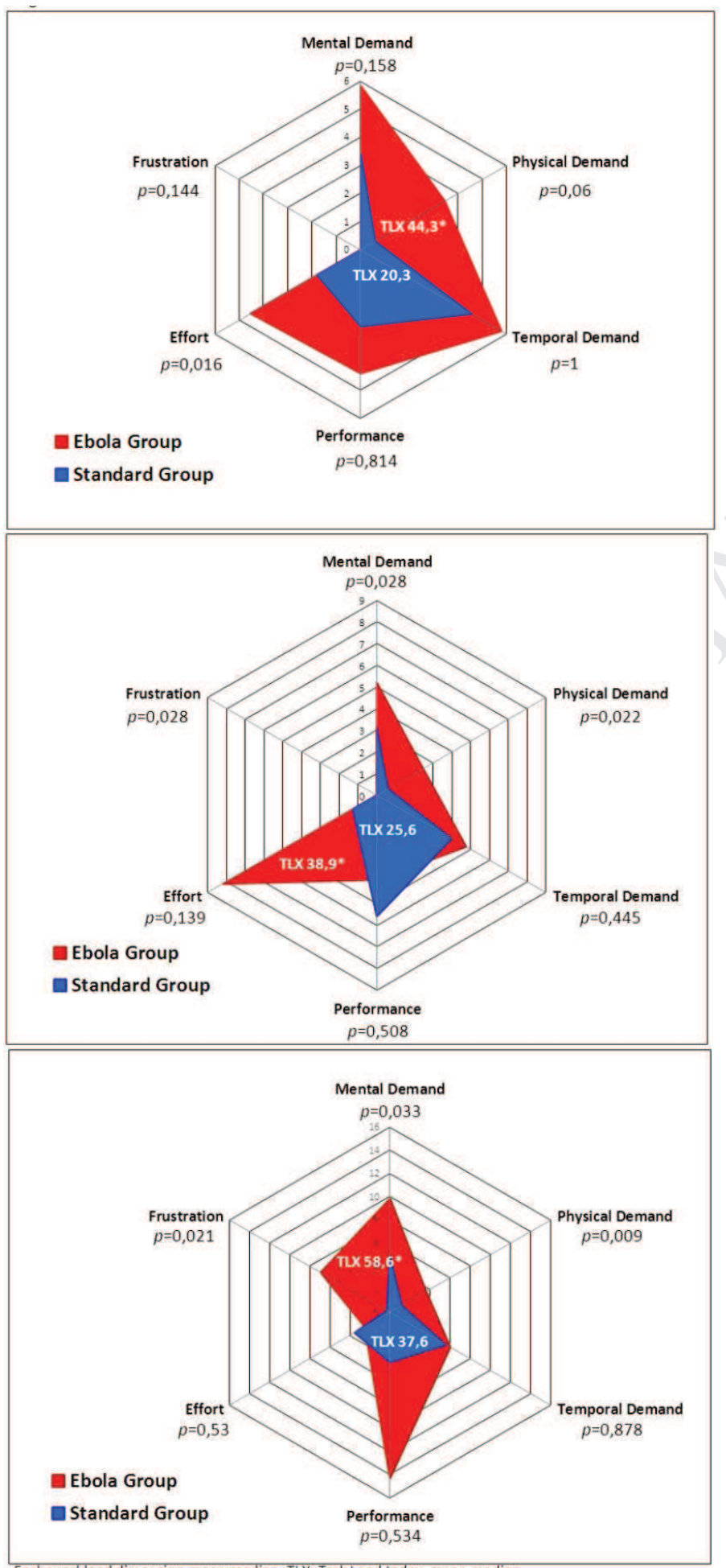


Table 1. Comparison of physiological conditions and ergonomics during common intensive care medical procedures with Ebola personal protective equipment (PPE), and with standard protection

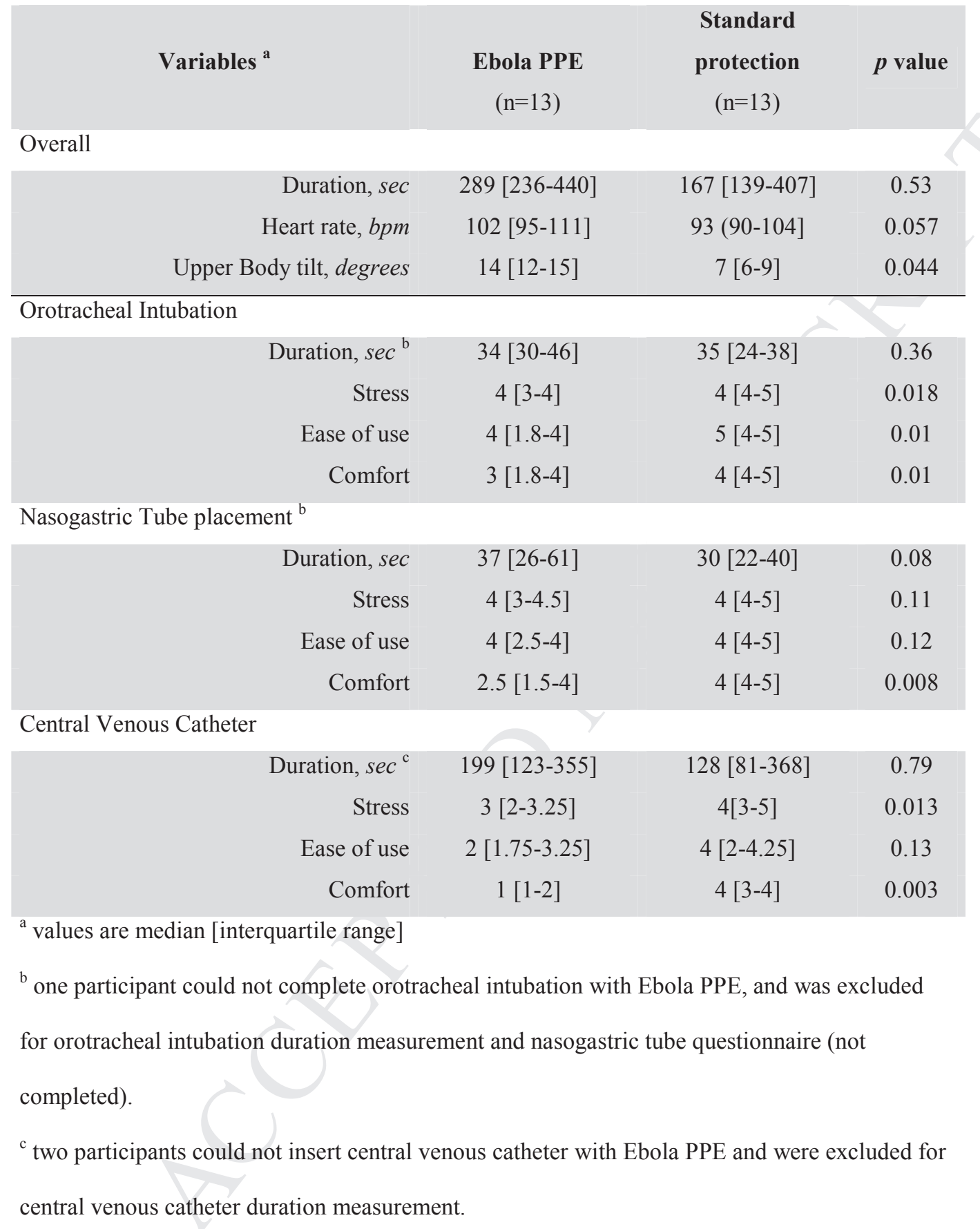

Stress, Ease of use and comfort during the procedures are Likert scales from 1 to 5: For Stress during the task, 1 for major stress and 5 no stress; for ease of use, 1 very difficult and 5 very easy; for comfort, 1 very uncomfortable and 5 very comfortable. 